\title{
Hydrogeological modelling to support urban planning in harbour areas: A case study from Horsens, Denmark
}

\section{Xinyu Cen ( $\nabla$ cenxinyukl2@163.com )}

Chengdu University of Technology https://orcid.org/0000-0002-6440-0009

\section{Anna Bondo Medhus}

VIA University College

Theis Raaschou Andersen

VIA University College

\section{Søren Erbs Poulsen}

VIA University College

Mo Xu

Chengdu University of Technology

\section{Zishen Mou}

Chengdu University of Technology

\section{Feng Du}

Chengdu University of Technology

\section{Research Article}

Keywords: Brownfield redevelopment, Groundwater contamination, Transport modelling, Phenols, FEFLOW

Posted Date: June 14th, 2021

DOI: https://doi.org/10.21203/rs.3.rs-212748/v1

License: (c) (1) This work is licensed under a Creative Commons Attribution 4.0 International License. Read Full License 


\section{Hydrogeological modelling to support urban planning in}

2 harbour areas: A case study from Horsens, Denmark

3 Xinyu Cen ${ }^{1}$, Anna Bondo Medhus ${ }^{2}$, Theis Raaschou Andersen ${ }^{2}$, Søren Erbs Poulsen ${ }^{2}$,

$4 \mathrm{Mo} \mathrm{Xu}^{1}$, Zishen $\mathrm{Mou}^{1}$, Feng $\mathrm{Du}^{1}$

51 State Key Laboratory of Geohazard Prevention and Geoenvironment Protection, 6 Chengdu University of Technology, Chengdu 610059, China

$7 \quad{ }^{2}$ Research Centre for Built Environment, Energy, Water and Climate, VIA University

8 College, Chr. M. Østergaards Vej 4, 8700 Horsens, Denmark

9 Abstract

10 Historically, industries were in harbour areas of cities for easy access to transportation of resources.

11 Today, transforming former industrial areas into living spaces has become attractive business. However,

12 this transformation has often been challenged by high levels of soil contamination caused by the

13 industrial use. Remediation measures are mandatory to ensure the public safety in the redeveloped areas.

14 Detailed information about the contaminant type, distribution and transport mechanisms is required to

15 address the contamination issues. This paper presents a workflow for investigations assisting decision

16 making for construction work in redeveloped industrial areas. The workflow is applied to Horsens

17 harbour (Denmark). In this area, renovation of the harbour walls introduces the risk of spreading of

18 phenol contamination to planned construction areas. The study demonstrates how detailed information

19 about the geology and hydrology at the site allows for scenario modelling of contaminant transport,

20 guiding remediation efforts and aiding decision makers in developing the harbour area.

21 Keywords: Brownfield redevelopment, Groundwater contamination, Transport modelling, Phenols, 22 FEFLOW

\section{Acknowledgements}

24 The authors are greateful to the municipality of Horsens and the Central region of Denmark for providing 25 relevant data to the project.

\section{Declarations}

27 Funding: This article was funded by the State Key Laboratory of Geohazard Prevention and

28 Geoenvironment Protection (Chengdu University of Technology) (Grant No. SKLGP2020K002).

29 Conflict of Interest: The authors declare that they have no conflict of interest.

30 Availability of data and material: Not applicable 
Affiliations:

State Key Laboratory for Geohazard Prevention and Geoenvironment Protection, Chengdu University of Technology, No 1, Rd.3, Erxianqiao East, Chengdu, 610059, China

Xinyu Cen (cenxinyuk12@163.com), Mo Xu (xm@cdut.edu.cn), Zishen $\quad$ Mou (mouzishen17@cdut.edu.cn) and Feng Du (dufeng2012@cdut.edu.cn)

Research Centre for Built Environment, Energy, Water and Climate, VIA University College, Chr. M. Østergaards Vej 4, 8700 Horsens, Denmark

Anna Bondo Medhus (anbm@via.dk), Theis Raaschou Andersen (thra@via.dk) and Søren Erbs Poulsen (soeb@via.dk)

Corresponding authors:

Xinyu Cen (cenxinyuk12@163.com) and Mo Xu (xm@cdut.edu.cn)

\section{Introduction}

Groundwater in urban areas is exposed to anthropogenic influences and is often contaminated (Vasin et al., 2016). Various sources of contamination can exist and challenge remediation efforts and future redevelopment due to changing land use (Schirmer et al., 2013). Therefore, the practical contaminated site investigations and measures to determine the transport of contaminants in urban areas are necessary and have been scientifically scrutinised for several years (Bauer et al., 2004; Greis et al., 2012; Trowsdale and Lerner, 2007; Vasin et al., 2016). However, insufficient information about the hydrogeological setting and the numerical transport model have made the evaluation of contaminant concentration and distribution significantly uncertain (Hansen et al., 2019; Yang et al., 1999). Consequently, the effects of collection and remediation schemes developed seldom meet expectations (Graber et al., 2008; Khan et al., 2004).

Knowledge of the hydrogeological setting in urban areas is crucial because it forms the basis for understanding the fate and distribution of the contaminants. In recent years, hydrogeophysical methods have become a valuable, non-invasive source of continuous data sections, significantly improving the data coverage and accuracy of the investigated urban areas (Bockhorn et al., 2015; Pazzi et al., 2016; Prudhomme et al., 2019). Geophysical methods have been applied at contaminated sites to identify fill materials and, in some cases, map contamination plumes (Boudreault et al., 2010; Maurya et al., 2017;

61 Vaudelet et al., 2011). However, the anthropogenic structures in urban areas represent abrupt changes

62 which sometimes shortcut the geological units. Hence, the urban hydrogeological models often suffer 
from low fidelity which reduces the accuracy of numerical simulations. Consequently, it is important to include those features in the urban models (Andersen et al., 2018).

Mapping contaminant plumes provides a better understanding of contaminated sites which enables sound risk assessment and targeted remediation schemes (Tao et al., 2019). The first step to delineate the geometry of contaminant plumes is usually point sampling. Recently, the mapping approach was developed from a simple interpolation to novel methods including stable isotopes tracing, geophysical mapping, geostatistics and hypothetical numerical simulation (Baawain et al., 2018; Karges et al., 2018; McLean et al., 2019; Negrel et al., 2017; Pannecoucke et al., 2020; Rivett and Allen-King, 2003; Zuo et al., 2018). Once the outline of contaminants has been revealed, the treatment technology takes over. Many in-situ and ex-situ approaches, including permeable reactive barriers, capture wells and electrochemical transformation, have been tested and proven effective (Bertrand et al., 2016; Christ and Goltz, 2004; Hyldegaard et al., 2020; Vaezihir et al., 2020). In some cases, the polluted areas are too large or expensive to considered remediation on a shorter time scale. If construction work is planned in such an area, it is beneficial to model the resulting changes in the expected flow pattern. This may mitigate the risk of spreading pollution.

Recently, 3D numerical flow and solute transport software and code, including FEFLOW (Finite Element subsurface FLOW system), Visual MODFLOW and CSTREAM, have attracted considerable interest due to their excellent functionality and flexibility (Bauer et al., 2004; Jeppesen et al., 2011; Trowsdale and Lerner, 2007). FEFLOW has been successfully applied to simulate groundwater recharge and denitrification below a seasonal flooded restored riparian zone, as well as for constructing a freshwater management system and assessing seawater intrusion in coastal aquifers (Elad et al., 2017; Jensen et al., 2017; Kazmierczak et al., 2016; Nocchi and Salleolini, 2013; Priyanka et al., 2018; Rona et al., 2014; Sherif et al., 2012). In urban areas, FEFLOW also acts as a reference for groundwater resource management and underground space engineering (Du et al., 2016; Greis et al., 2012; VazquezSune et al., 2005). In recent years, the solute transport simulation has played an increasingly important role in forming remediation schemes for groundwater (Bauer et al., 2004; Mulligan and Yong, 2004; Vasin et al., 2016). This paper evaluates the resultant shape of a contamination plume simulated for different possible scenarios suggested in the context of renovation and construction works planned in the Horsens harbour area. The example demonstrates how the simulation may help decision making.

Horsens harbour (Fig. 1) was formerly an industrial area from 1860 to 1969 consisting of gasworks, an asphalt roofing factory and a tar production facility. It was found that the former gasworks site was characterized by multiple contaminant sources. The contaminants of concern had the potential to continuously feed the contaminant plumes (Birak and Miller, 2009; Bockelmann et al., 2001; Mak et al., 2006). Today the upper meters of soil are still heavily contaminated even though the area was remediated in the 1980s and 1990s. Nonetheless, converting the industrial port into living spaces has become an attractive business because people willingly pay higher rent to live near the sea. 
and numerical methods such as geophysical mapping, 3D hydrogeological model construction and solute transport simulation in an urban area to help plan the renovation at a harbour front to guide water to the sea while considering various interests. Andersen et al.'s work presents (2018) a detailed 3D geological model of the former gasworks at Gasværksgrunden in Horsens, Denmark. The previous work was based on joint interpretation of various geophysical methods, boreholes, water samples and land use information. Building on these premises, the research objectives of this paper are

(1) to import the 3D hydrogeological voxel model to FEFLOW by assigning proper hydrogeological parameters for it,

(2) to explore the transport of the contaminant plume according to the identified contamination source information,

(3) to evaluate the changes in the contaminant plume for different scenarios related to the renovation of the sheet pile walls.

\section{Suggested workflow}

This section suggests a workflow (Fig. 2) which has been developed and tested as part of this study. The field geophysical mapping, lithological and anthropogenic data interpretation for the 3D geological model construction in GeoScene3D have been detailed by Andersen et al. (2018). Based on their research, this paper focuses on the hydrological parametrization of the 3D geological model and simulation of different scenarios in FEFLOW. Thus, these are parts of the workflow detailed in later sections of this article for Horsens harbour. To frame the rest of the work presented in the study, this section will go through the suggested workflow.

Initially all relevant data from the site are acquired. Studying the fate of contaminants requires detailed information about the study area. This includes borehole data, geophysical data, water level measurements, water sample analyses, terrain elevation data, orthophotos for evaluation of infiltration, reports from the area, distribution of anthropogenic features among others including pipes, basements and information about former excavations and fill materials. After the data collection, whether additional data needs to be acquired is decided based on assessing the data coverage. Once the data coverage is reasonable, considering the expected geological complexity, a 3D hydrogeological model representing lithology is created. For information on data collection and setup of the hydrogeological model for the area of Horsens harbour, please refer to Andersen et al. (2018). The model is imported into FEFLOW and relevant hydrogeological parameters are assigned. The discretisation and relevant parameters assigned in FEFLOW are detailed in section 5, using Horsens harbour as an example. Once the

137 calibrated to fit water levels observed in the study area. When the hydrological model is calibrated it is 
possible to build up the fluid flow and solute transport model. For the case of Horsens harbour the sheet pile walls are adjusted in the simulations according to the suggested scenarios. The simulations reveal changes in the geometry of the contaminant plumes arising in the different situations. Decisions can be made based on the observed differences for the chosen scenarios. This article assesses the applicability and effectiveness of different scenarios and their potential impact on hydrogeological conditions and contaminant transport in the research area. Finally, the optimal solution is selected and the results are presented to the decision makers in Horsens municipality for conclusion and application.

\section{Site description}

The study is conducted on the Horsens Gasworks site, Denmark (Fig. 1). The site is designated as one of the nine national test sites for the development and demonstration of new techniques related to the investigation and prevention of soil contamination (https://www.danishsoil.org/testsites/index.php?lang=uk). Various urban features including roads, houses, parking lots and green areas constitute this area. An estimated 45,000 $\mathrm{m}^{3}$ of soil is still heavily contaminated due to the contaminant spread before the remediation efforts in the 1980s and 1990s. Today, up to 5 to $7 \mathrm{~m}$ of the upper soil is contaminated with volatile aromatics, phenols, polycyclic aromatic hydrocarbons $(\mathrm{PAH})$ and inorganic compounds. The degradation rate of the contaminants is expected to be extremely slow due to the anaerobic conditions which hinder the reproduction of aerobic microorganisms that might degrade the contaminants. A contamination plume has been detected along the western part of the area that extends towards the harbour. It is believed to originate from the gasworks vicinity field (Krüger A/S, 1990; Krüger A/S, 1998; Krüger A/S, 1999).

The land and sea areas are originally separated by two sheet pile walls (named Wall 1 and Wall 2, respectively, see Fig.1). Wall 2 is a concrete structure and considered impermeable while Wall 1 is an old wooden structure which is permeable. Due to the ongoing degradation, Wall 1 is about to be replaced by an impermeable steel structure. This modification is expected to change the hydrological conditions and, consequently, influence the transport pattern of the contaminants. Simultaenosuly, several construction sites including commercial and residential projects have been scheduled in the Horsens harbour area. An impermeable Wall 1 is expected to widen the contamination plume and increase the concentration of contaminants in the planned construction sites. This should be avoided. Thus, different solutions are being tested.

\subsection{Geology}

The geology at Horsens harbour is complex, with sediments ranging from glacial to post-glacial and anthropogenic sediments. The glacial deposits include moraine clay, thin layers of meltwater deposits overlain with lacustrine clays and silt. The glacial sediments were deposited during the Pleistocene (Houmark-Nielsen, 2004). The postglacial sediments include several thin layers of sand, clay and organic clay (Gyttja) deposited during the Holocene when the area experienced several regressions/transgressions (Houmark-Nielsen, 2004). The glacial and postglacial deposits are overlain with fillings that display abrupt lateral variations and thicknesses up to $5 \mathrm{~m}$. The fillings around anthropogenic structures, for e.g. pipes lines, sewers and foundations, are predominantly sand and gravel. 


\section{Hydrogeological model}

\subsection{Borehole data}

The lithological information from 98 boreholes at the field site was collected from the national borehole database, Jupiter, hosted by The Geological Survey of Denmark and Greenland (GEUS), various geotechnical investigations at the field site and the Central Region of Denmark's database (Fig.3). The borehole depth varies from $0.5 \mathrm{~m}$ to $28 \mathrm{~m}$ below terrain (m.b.t.) with most boreholes being drilled to around 7 m.b.t. In addition to the lithological information for several boreholes, the databases provide information about the groundwater level and chemical analyses. The quality of the borehole information varies due to differing borehole ages, drilling purposes and drilling methods.

\subsection{Groundwater level}

Geophysical surveys and borehole information suggested the presence of two sandy aquifers in the study area. The upper aquifer is mainly distributed in the central and northern part of the model whereas the lower aquifer is thinner but generally continuously spread over the study area. The groundwater levels in the aquifers were derived from the available borehole information, section 4.1. Data was filtered to obtain the authentic water level representing the continuous groundwater flow field in the aquifers rather than stagnant water lenses, discontinuous or deeper water levels. Hence water level data from boreholes were selected only if the screen, or the bottom, in case of open boreholes, was in the upper or lower sandy aquifer. Additionally, outliers, where the hydraulic head listed was above the terrain or far deeper than most of the measured values, were discarded. Finally, 52 qualified boreholes were selected based on the above conditions (Fig. 5). In some boreholes, series of measures were available at different times. In such cases, the median value was adopted. Still, variation in water levels sustained, most likely due to seasonal changes, tides and rainfall differences since measurements were not conducted at the same time. Ideally, a synchronous series of measurements should be undertaken. This was not possible here since the boreholes were temporary and often originated from geotechnical investigations before construction works. The upper aquifer has a hydrostatic pressure around 3.383 to $3.708 \mathrm{~m}$ above sea level. The hydraulic head in the lower aquifer varies from -0.8 below sea level to $2.3 \mathrm{~m}$ above sea level. The groundwater elevation generally decreases from north to south.

\subsection{Analyses}

Analyses of water samples from 29 boreholes, soil samples from 12 boreholes and pore air from 5 boreholes are available from the study area (Fig. 6). The samples were analysed for various components among others volatile aromatics. For e.g., benzene, phenols, polycyclic aromatic hydrocarbons (PAH), naphthalene and inorganic components such as cyanide, ammonia and sulphate. Furthermore, NVOC (Non-Volatile Organic Carbon), electrical conductivity, pH, redox potentials and temperature. This article aims to investigate the transport of contaminants from the gas works stations. Phenols were selected as an indicator of spreading contamination based on their high water solubility and slow degradation (Broholm et al., 1999). Information from the analyses was applied for locating the source of the contamination and verification of the simulations.

\subsection{Geophysical data}

It was concluded that continuous and area covering data was essential to resolve the geology in detail for modelling of contaminant transport. Therefore, geophysical investigations were conducted on 
a $200 \mathrm{~m} \times 330 \mathrm{~m}$ test site to construct a high-resolution geological model (Andersen et al., 2018). The

217 extensive geophysical datasets detailed in Andersen et al. (2018) included DualEM-421, GPR and

218 DC/TDIP (Fig. 3). During the investigation, two ground penetrating radar (GPR) profiles and ten direct

219 current (DC) resistivity and time domain induced polarization (TDIP) profiles were measured. Moreover,

220 a total of $5500 \mathrm{~m}$ of profiles were measured in two surveys with the DualEM-421.

\subsection{Anthropogenic structures}

The buried anthropogenic features expected to affect the flow of ground water in the area include sewer systems, water pipes, cables and houses with basements. Information on these was provided as georeferenced features by Horsens Municipality. Cables are generally expected to be located no deeper than 0.8 m.b.t. while sewers and water pipes are placed from terrain to approximately 1.25 m.b.t. The depth of basements is assumed to be $1.8 \mathrm{~m}$ (Fig. 4).

\subsection{Voxel model}

The information from the geophysical mapping, boreholes and location of anthropogenic features were imported to an interpretation software - GeoScene3D (www.I-GIS.dk) - which conducted an integrated interpretation, as described in Andersen et al. (2018). As an alternative to the traditional surface modelling approach, the geological property variations and anthropogenic structures were represented in a regular 3D grid. Material parameters are assigned to each 3D cell (voxel) in the grid, allowing for heterogeneity, abrupt changes and properties that vary within lithologies (Jessell, 2001). In this study, the georeferenced information about anthropogenic structures has been included in the geological 3D voxel model.

For the gasworks model, voxels can delineate the geological structures and characterize anthropogenic features within the uncertainty of the mapping methods. Structures smaller than the voxels can possibly exists, but they will be below the resolution of the applied mapping methods. In the following optimization process, the voxel model was reviewed and adjusted by geologists to achieve the best match between the model presentation and geological interpretation.

The voxel model contains information about a 5-7 m layer below the crust. Because of topography and local information about greater depth, the model extends from $3.75 \mathrm{~m}$ above sea level to $11.25 \mathrm{~m}$ below sea level with voxels measuring $1 \mathrm{~m} \times 1 \mathrm{~m} \times 0.5 \mathrm{~m}(\mathrm{x}, \mathrm{y}, \mathrm{z})$. The topsoil fillings are dominated by sand and minor interactions of clay and silt ranging between 1 and $5 \mathrm{~m}$ in thickness. Under the fillings, a 1-3 m thick layer of medium to coarse grained sand is observed. Below the sand, a series of thin discontinuous 0.5-2 $\mathrm{m}$ thick clay and silt deposits are observed. A 2-10 m thick unit alternating from medium grained sand to silt and clay layers (Fig.4) lies under the clay and silt layers.

\section{FEFLOW modelling}

The high-resolution hydrogeological voxel model forms the basis for estimating the groundwater 
model simulating confined groundwater flow and contaminant transport was utilised. The numerical code developed by Hans-Jörg G. Diersch in late 1970s is one of the most widely used codes in modelling solute transport for groundwater. The flow and solute transport equations are (Diersch, 2013)

$$
\nabla \cdot(\bar{q})=Q
$$

where, $\bar{q}=-K \cdot \nabla h$ (Darcy equation); $Q=$ volumetric flow rate of source/sink term $\left[\mathrm{T}^{-1}\right] ; C=$ solute concentration; $\bar{D}=\varepsilon B D_{m} \delta+D ; D_{m}=$ molecular diffusion coefficient $\left[\mathrm{L}^{2} \mathrm{~T}^{-1}\right] ; B=$ thickness of saturated phreatic aquifer [L]; $\delta=$ identity tensor; $\varepsilon=$ effective porosity; $D=$ mechanical dispersion tensor $\left[\mathrm{L}^{2} \mathrm{~T}^{-1}\right]$.

\subsection{Model discretization}

The model domain covers 553,819.5 to $554019.5 \mathrm{~m}$ Easting and 6,190,599.5 to $6190929.5 \mathrm{~m}$ Northing, as per European Terrestrial Reference System (ETRS) 89 / Universal Transverse Mercator (UTM) zone $32 \mathrm{~N}$ in the horizontal plane. The elevation of the top and bottom of the model is $3.75 \mathrm{~m}$ above and $11.25 \mathrm{~m}$ below the mean sea level, respectively. The model is a cuboid spanning $200 \mathrm{~m}$ (UTM$\mathrm{X}) \times 330 \mathrm{~m}(\mathrm{UTM}-\mathrm{Y})$ horizontally and $15 \mathrm{~m}$ in vertically. Voxel dimensions are uniformly set to $1 \times 1$ $\times 0.5 \mathrm{~m}(\mathrm{x}, \mathrm{y}, \mathrm{z})$. Thus, the model has a total of 1,980,000 elements (i.e., 66,000 elements in each layer) and 2,062,461 nodes. To simplify the calculation, part of the elements representing seawater, impermeable anthropogenic structures and elements without geological information were set as computationally inactive.

\subsection{Model inputs}

The initial and calibrated model parameters have been listed in Table.1

Land use information was provided as georeferenced features by the Horsens municipality. Infiltration areas for numerical simulations were defined based on this information. The precipitation infiltration was the main inflow on top of the aquifer. Buildings and impermeable land cover such as roads were assigned zero infiltration. The recharge was computed by multiplication of the recharge coefficient with the annual precipitation data. The mean annual precipitation and soil infiltration coefficient were estimated to be $880-950 \mathrm{~mm} / \mathrm{year}$ and $23.5 \%$, respectively by Severinsen et al. (1996) and Stisen et al. (2012). A uniform precipitation of $900 \mathrm{~mm} / \mathrm{year}$ was applied for the study area which corresponds with an annual infiltration of $212 \mathrm{~mm} /$ year.

\section{Boundary conditions}


interpolation of observed groundwater levels for each aquifer (Bartier and Keller, 1996; Yao et al., 2014). Due to the impenetrability of the structures located outside the southern study area, the southern boundary was set as a no-flow condition over the entire depth. The no-flow boundary was also defined along the eastern and western boundaries since the overall flow direction of the groundwater was north to south (Andersen et al., 2018). The bottom of the model was also considered as a no-flow boundary. At nodes where the model was not specifically defined, the default impermeable boundary condition was maintained.

\section{Material properties}

Voxel cells from the hydrogeological model were assigned with hydraulic conductivities on import to FEFLOW. The chosen hydraulic conductivity was based on lithological definitions, field observations, empirical values and results of previous studies (Fredericia, 1990; Henriksen et al., 2003; Heron et al., 1998; Sidle et al., 1998). The conductivity value of each unit was found to be spatially varying and anisotropic in the vertical direction i.e., $K_{x x}=K_{y y} \neq K_{z z}$. The vertical hydraulic conductivity was assumed to be $10 \%$ of the horizontal conductivity in the $x$ or $y$ plane (Priyanka et al., 2018). The porosity was considered uniform and set to 0.3 for all units.

\section{Flow model calibration}

The flow model was calibrated by comparing observed and calculated hydraulic heads in the lower sand aquifer in boreholes using varying horizontal and vertical hydraulic conductivities. The accuracy of the calibrated models was estimated with the root-mean-square error (RMSE):

$$
R M S E=1 / n \sqrt{\sum\left(H_{\text {obs }}-H_{\text {sim }}\right)^{2}}
$$

where, $H_{o b s}$ is the observed hydraulic head, $H_{s i m}$ is the simulated hydraulic head, and $n$ is the number of data points.

\section{Contaminants transport}

The initial mass concentration of the model was set at zero to simulate the impact of the contaminants, which originated from the identified contamination source, on the whole model area. The mass boundary conditions on the northern nodes were assigned with a zero boundary since the groundwater flow direction was expected to be roughly southwards. The Scheidegger-Bear model was used for the mechanical dispersion in which the transverse dispersion was assumed to be isotropic (Raats, 1973). Both longitudinal and transverse dispersion coefficients depended on the spatial scale of the model domain and were uniformly set to $7.5 \mathrm{~m}$ and $0.75 \mathrm{~m}$ respectively (Gelhar et al., 1992).

The contamination source corresponds to the hot spot area at the gasworks site, as shown by Andersen et al. 2018 (Fig. 4). In the vertical direction, boreholes indicated the presence of sandy sediments below the groundwater table. Moreover, resistivity and chargeability profiles from 10 DC/TDIP profile lines (Fig. 3) suggested that sandy sediments located in the saturated zone were heavily 
simulated with the elements from layer 5 to layer 7 that were predominantly sand (Fig. 4). The

321 dimensionless unit mass concentration boundary condition was assigned to the nodes of the source elements. With this normalized approach, the simulations revealed the spread of contaminants and the resultant dilution factor to be applied while estimating the concentrations of contaminants spreading from the source location. The contaminant transport was assumed to be conservative.

\section{Results and discussion}

\subsection{The hydrological model}

Fig. 5 illustrates the boundary conditions in the model, the simulated hydraulic head distribution in the lower aquifer and 52 observed hydraulic heads in the study area. The simulated contours show how the hydraulic head is highest near the northeast and gradually decreases from north to south, as it approaches zero at Wall 1. Some discrepancy is observed between manual and simulated values as well as between closely lying manual measures. Observed values are generally lower than the ones simulated in the harbour area and higher than the simulated values at the north of the model. Manual measures have not been conducted simultaneously; some are years apart. It was concluded that measurements made at the same time appear to show similar levels, decreasing from north to south, towards the harbour front in accordance with the simulations. Boreholes with over five measures have values varying by over a meter. With asynchronous measures, variations may originate with seasonal change, human activities, tides and recent precipitation. Nevertheless, measuring boreholes with high-density distribution offers possibilities to acquire relatively authentic data representing the continuous groundwater flow field.

Fig. 6 shows the modelled original distribution of the contaminant plume in the sandy aquifer. The values represent the maximum modelled concentration of contaminants in the aquifers presented below that point in the model. The dashed line represents contaminant reduction to $5 \%$ of the source concentration and approximates the outline of the contamination plume. Additionallly, the solid line is plotted to highlight the isoline with a concentration of $35 \%$ of the source concentration. This isoline is chosen because it approximates half the distance between the contamination source and the edge of the plume. Besides, this isoline can illustrate the main flow direction of the contaminants. The two black curves representing this original case scenario have been maintained in following figures for comparison to highlight the changes in the flow direction and extent of contaminants when the harbour Wall 1 is renovated.

Fig. 6 reveals a southward migration of contaminants - away from the source. This is in accordance with the general north to south flow of groundwater. The plume widens and the concentrations decreases southwards. The areas located south of the source, including the gasworks area, streets and the western part of the site 1 are the main contaminated areas while site 2 is at a lower risk of contamination. The permeable Wall 1, representing the shortest hydraulic distance to the sea, implies a discharge at the western part of the wooden harbour wall. Consequently, installing the outflow control facilities on the wall is recommended. This will drain the contaminated groundwater to prevent the expected spreading if the contaminated water cannot escape and is forced onto a longer path. Furthermore, it will have contaminants flowing out at a known position, ready for remediation work in the future. 
Fig. 6 compares the modelled plume and observations from groundwater samples (circles), soil samples (triangles), and pore air samples (crosses). The red symbols show locations where phenols were detected. Green symbols represent locations of analyses with no phenols detected. With phenol analyses carried out at different times, on different sample types and possibly using different methods, the figure shows whether phenols were detected rather than the detected phenol concentration. Phenols do not evaporate into the pore air easily. That might be the reason why some green crosses representing pore air samples were located where groundwater samples indicate presence of phenols. Furthermore, pore air analyses were collected between the depths of 0.3 and $0.8 \mathrm{~m}$ below the terrain, often in fillings or organic soils located above the aquifers from which water samples had been collected. Results from soil samples showed an unclear pattern. These samples were also collected at shallow levels, generally less than 1 to $2 \mathrm{~m}$ depth, typically in layers consisting of gyttja or fillings. The harbour area was a former industrial area with piles of various materials lying on the ground available to the industry needing it. Thus, it is expected that the findings in shallow soil samples originated from the local contamination related to former storage spaces.

\subsection{Scenario and prediction}

The outflow control facilities comprise a perforated drainage pipe supplied with two outlet pipes. The drainage pipe is $10 \mathrm{~m}$ long and installed parallel to the wall. The two 2-m-long outflow pipes connect the drainage pipe to the sea, see Fig.7 b, c and d.

Geophysical surveys and borehole information suggest the presence of two sand layers in the study area. An upper, $1 \mathrm{~m}-3 \mathrm{~m}$ thick sand layer to the north which thins out and becomes discontinuous to the south, pinching out near the Walls (Fig.4). The lower sand layer gradually increases in thickness from north to south. Although the lower sand generally appears thinner than the upper sand layer, it seem to be continuous over the area and can provide ideal conditions for the groundwater and contaminants. The analysis of groundwater samples and electrical resistivity data revealed that both the sand layers were contaminated (Andersen et al., 2018). The upper sand layer failed to provide a continuous migration path for contaminants due to the pinch out before reaching the wall, where the facilities were supposed to be located. Hence, to avoid disturbing the original flow pattern, the outflow control facilities were installed in the lower sand layer.

Subsequently, three scenarios have been designed to determine the best location for the outflow control facilities (Fig.7 b, c, d). In the first two scenarios, the facilities have been placed on the western part of Wall 1 with the concentrated contaminant discharge into the sea, as shown in Fig.7 a. Conversely, the third scenario is placed on the Wall 2, to test whether installing the facilities on this Wall can reduce the plume width. In these scenarios, the outflow control facilities are arranged at intervals of around 10

$391 \mathrm{~m}$. The outflow control facilities are implemented in the numerical model by assigning the nodes on the 392 drainage pipe as a fixed hydraulic head (i.e., $0 \mathrm{~m}$ ) since the drainage pipe is connected to the sea through 393 the outlet pipes.

Fig. 7 (colour-filled contours) shows the distribution of the contaminants' plumes in the three 
case (grey area enclosed by black dashed lines). Compared to the original case, the covered areas of the contamination plumes in the first two scenarios (Fig. 7b and c) were effectively reduced, especially at site 1. However, installing a larger plume on Wall 2 is predicted to cause a contamination spread over new areas, especially for site 2 . Thus, scenario 3 was discarded.

In scenarios 1 and 2 (see Fig.7 b and c), the outflow control facilities were placed on the western part of Wall 1, where the concentrated contaminants originally discharged into the sea. For site 1 , the area covered by the plume were effectively reduced in the two scenarios. Scenario 1 was the better solution in the context of the number of reduced areas. Moreover, concentrations near the facilities in scenario 1 were obviously higher than scenario 2 . Therefore, more contaminants were discharged by the facilities installed in scenario 1 than scenario 2 during the same period. Although different scenarios were tested to minimize the impact of contaminants, it was inevitable that site 1 and the streets would still be located right in the path of the plume.

The main purpose of installing the outflow control facilities is avoiding an additional spread of contaminants compared to the original situation while renovating Wall 1 and making it impermeable. Under this condition, the recommended solution would be installing facilities west of Wall 1, near Wall 2, as shown in Fig. 7b. In addition to fulfilling this requirement, the most important thought behind the planned solution is the installation of these facilities provides an accurate position for future collection and remediation work compared to the widespread discharge areas in the original case. Additionally, the selected solution can effectively mitigate the impact of contaminants on site 2 and discharge more contaminants.

To illustrate the average distribution of all kinds of contaminants in the study area, the dimensionless unit concentration boundary condition was assigned to source nodes. Moreover, the mass transport was conservatively set. There are several types of contaminants characterising different chemical reactions and physical processes in the soil and groundwater. However, acquiring the accurate composition and related parameters as well as systematic concentration testing work are absent. Therefore, based on the results of this study, subsequent research should not only focus on the collection and treatment of contaminated groundwater at outflow control facilities but also establish more accurate solute transport-reaction and degradation models, building on the relevant data and parameters.

\section{Conclusions}

This study suggests a workflow for planning the transformation of a polluted industrial area into a living space. The workflow includes data assessment and collection, construction of a 3D hydrogeological model integrating anthropogenic features and information on infiltration. It also includes simulations and scenario testing designed to answer questions relevant for the decision about the transformation process. The workflow has been successfully applied at Horsens harbour, Denmark. Simulations have been verified by comparing the models and the available data from the site. Scenario testing designed for decision making was undertaken. The results of numerical simulations suggest that the optimal location for installing outflow control facilities guiding a flow of contaminants. By knowing the location of the outflow of the contaminants, they are ready for treatment and remediation work. The 
installation scheme effectively mitigates the impact of contaminants on two planned construction sites. This study demonstrates the way modelling of contaminant transport based on detailed hydrogeological information for different scenarios can assist decision making about complex urban contaminated sites.

\section{References}

Andersen TR, Poulsen SE, Thomsen P, Havas K (2018) Geological

characterization in urban areas based on geophysical mapping: A case study

from Horsens, Denmark. J Appl Geophys 150:338-349.

https://doi.org/10.1016/j.jappgeo.2017.08.009

Baawain MS, Al-Futaisi AM, Ebrahimi A, Omidvarborna H (2018) Characterizing leachate contamination in a landfill site using Time Domain Electromagnetic (TDEM) imaging. J Appl Geophys 151:73-81.

https://doi.org/10.1016/j.jappgeo.2018.02.002

Bartier PM, Keller CP (1996) Multivariate interpolation to incorporate thematic surface data using inverse distance weighting (IDW). Comput Geosci 22:795799. https://doi.org/10.1016/0098-3004(96)00021-0

Bauer S, Bayer-Raich M, Holder T, Kolesar C, Muller B, Ptak T (2004)

Quantification of groundwater contamination in an urban area using integral pumping tests. J Contam Hydrol 75:183-213.

https://doi.org/10.1016/j.jconhyd.2004.06.002

Bertrand G, Hirata R, Pauwels H, Cary L, Petelet-Giraud E, Chatton E, Aquilina L, Labasque T, Martins V, Montenegro S (2016) Groundwater contamination in coastal urban areas: Anthropogenic pressure and natural attenuation 
processes. Example of Recife (PE State, NE Brazil). J Contam Hydrol 192:165-

180. https://doi.org/10.1016/j.jconhyd.2016.07.008

Birak PS, Miller CT (2009) Dense non-aqueous phase liquids at former

manufactured gas plants: Challenges to modeling and remediation. J Contam

Hydrol 105:81-98. https://doi.org/10.1016/j.jconhyd.2008.12.001

461 Bockelmann A, Ptak T, Teutsch G (2001) An analytical quantification of mass

462 fluxes and natural attenuation rate constants at a former gasworks site. J

463 Contam Hydrol 53:429-453. https://doi.org/10.1016/S0169-7722(01)00177-2

464 Bockhorn B, Moller I, Klint KES, Jensen MB (2015) Geoelectrical mapping for

465 improved performance of SUDS in clay tills. Environ Earth Sci 74:5263-5273.

466 https://doi.org/10.1007/s12665-015-4535-z

467 Boudreault JP, Dube JS, Chouteau M, Winiarski T, Hardy E (2010) Geophysical

468 characterization of contaminated urban fills. Eng Geol 116:196-206.

469 https://doi.org/10.1016/j.enggeo.2010.09.002

470 Broholm K, Jorgensen PR, Hansen AB, Arvin E, Hansen M (1999) Transport of

471 creosote compounds in a large, intact, macroporous clayey till column. J

472 Contam Hydrol 39:309-329. https://doi.org/10.1016/S0169-7722(99)00040-6

473 Christ JA, Goltz MN (2004) Containment of groundwater contamination

474 plumes: minimizing drawdown by aligning capture wells parallel to regional

475 flow. J Hydrol 286:52-68. https://doi.org/10.1016/j.jhydrol.2003.09.012

476 Diersch H-JG (2013) FEFLOW: finite element modeling of flow, mass and heat 
transport in porous and fractured media. Springer Science \& Business Media,

478 Belin

479 Du MX, Zavattero E, Ma Q, Delestre O, Gourbesville P, Fouche O (2016) 3D 480 hydraulic modeling of a complex alluvial aquifer for groundwater resource 481 management. Procedia Eng 154:340-347.

482 https://doi.org/10.1016/j.proeng.2016.07.487

483 Elad L, Yoseph Y, Haim G, Eyal S (2017) Tide-induced fluctuations of salinity and 484 groundwater level in unconfined aquifers - Field measurements and numerical 485 model. J Hydrol 551:665-675. https://doi.org/10.1016/j.jhydrol.2016.12.045

486 Fredericia J (1990) Saturated Hydraulic Conductivity of Clayey Tills and the Role 487 of Fractures. Nord Hydrol 21:119-132. https://doi.org/10.2166/nh.1990.0009 488 Gelhar LW, Welty C, Rehfeldt KR (1992) A critical review of data on field-scale 489 dispersion in aquifers. Water Resour Res 28:1955-1974.

490 https://doi.org/10.1029/92WR00607

491 Graber E, Laor Y, Ronen D (2008) Aquifer contamination by chlorinated-VOCs:

492 the case of an urban metropolis megasite overlying the Coastal Plain aquifer in

493 Israel. Hydrogeol J 16:1615-1623. https://doi.org/10.1007/s10040-008-0366-2

494 Greis T, Helmholz K, Schoniger HM, Haarstrick A (2012) Modelling of spatial

495 contaminant probabilities of occurrence of chlorinated hydrocarbons in an

496 urban aquifer. Environ Monit Assess 184:3577-3591.

497 https://doi.org/10.1007/s10661-011-2209-1 
499 (2019) Groundwater dynamics and effect of tile drainage on water flow across

500 the redox interface in a Danish Weichsel till area. Adv Water Resour 123:23-39.

501 https://doi.org/10.1016/j.advwatres.2018.10.022

502 Henriksen HJ, Troldborg L, Nyegaard P, Sonnenborg TO, Refsgaard JC, Madsen

503 B (2003) Methodology for construction, calibration and validation of a national

504 hydrological model for Denmark. J Hydrol 280:52-71.

505 https://doi.org/10.1016/S0022-1694(03)00186-0

506 Heron G, Bjerg PL, Gravesen P, Ludvigsen L, Christensen TH (1998) Geology

507 and sediment geochemistry of a landfill leachate contaminated aquifer

508 (Grindsted, Denmark). J Contam Hydrol 29:301-317.

509 https://doi.org/10.1016/S0169-7722(97)00028-4

510 Houmark-Nielsen M (2004) The Pleistocene of Denmark: A review of

511 stratigraphy and glaciation history. Developments in Quaternary Sciences 2:35-

512 46. https://doi.org/10.1016/S1571-0866(04)80055-1

513 Hyldegaard BH, Jakobsen R, Ottosen LM (2020) Electrochemical transformation

514 of an aged tetrachloroethylene contamination in realistic aquifer settings.

515 Chemosphere 243:125340. https://doi.org/10.1016/j.chemosphere.2019.125340

516 Jensen JK, Engesgaard P, Johnsen AR, Marti V, Nilsson B (2017) Hydrological

517 mediated denitrification in groundwater below a seasonal flooded restored

518 riparian zone. Water Resour Res 53:2074-2094. 
520 Jeppesen J, Christensen S, Ladekarl UL (2011) Modelling the historical water

521 cycle of the Copenhagen area 1850-2003. J Hydrol 404:117-129.

522 https://doi.org/10.1016/j.jhydrol.2010.12.022

523 Jessell M (2001) Three-dimensional geological modelling of potential-field data.

524 Comput Geosci 27:455-465. https://doi.org/10.1016/S0098-3004(00)00142-4

525 Karges U, Becker J, Püttmann W (2018) 1, 4-Dioxane pollution at contaminated 526 groundwater sites in western Germany and its distribution within a TCE plume.

527 Sci Total Environ 619:712-720. https://doi.org/10.1016/j.scitotenv.2017.11.043

528 Kazmierczak J, Muller S, Nilsson B, Postma D, Czekaj J, Sebok E, Jessen S, Karan

529 S, Jensen CS, Edelvang K, Engesgaard P (2016) Groundwater flow and

530 heterogeneous discharge into a seepage lake: Combined use of physical

531 methods and hydrochemical tracers. Water Resour Res 52:9109-9130.

532 https://doi.org/10.1002/2016WR019326

533 Khan Fl, Husain T, Hejazi R (2004) An overview and analysis of site remediation

534 technologies. J Environ Manage 71:95-122.

535 https://doi.org/10.1016/j.jenvman.2004.02.003

536 Mak KS, Griebler C, Meckenstock RU, Liedl R, Peter A (2006) Combined

537 application of conservative transport modelling and compound-specific carbon

538 isotope analyses to assess in situ attenuation of benzene, toluene, and o-

539 xylene. J Contam Hydrol 88:306-320. 
541 Maurya PK, Ronde VK, Fiandaca G, Balbarini N, Auken E, Bjerg PL, Christiansen AV (2017) Detailed landfill leachate plume mapping using 2D and 3D electrical resistivity tomography - with correlation to ionic strength measured in screens.

544 J Appl Geophys 138:1-8. https://doi.org/10.1016/j.jappgeo.2017.01.019

545 McLean M, Evers L, Bowman A, Bonte M, Jones W (2019) Statistical modelling 546 of groundwater contamination monitoring data: A comparison of spatial and 547 spatiotemporal methods. Sci Total Environ 652:1339-1346.

548 https://doi.org/10.1016/j.scitotenv.2018.10.231

549 Mulligan CN, Yong RN (2004) Natural attenuation of contaminated soils.

550 Environ Int 30:587-601. https://doi.org/10.1016/j.envint.2003.11.001

551 Negrel P, Ollivier P, Flehoc C, Hube D (2017) An innovative application of stable 552 isotopes $(\delta 2 \mathrm{H}$ and $\delta 180$ ) for tracing pollutant plumes in groundwater. Sci Total

553 Environ 578:495-501. https://doi.org/10.1016/j.scitotenv.2016.10.214

554 Nocchi M, Salleolini M (2013) A 3D density-dependent model for assessment 555 and optimization of water management policy in a coastal carbonate aquifer 556 exploited for water supply and fish farming. J Hydrol 492:200-218.

557 https://doi.org/10.1016/j.jhydrol.2013.03.048

558 Pannecoucke L, Le Coz M, Freulon X, de Fouquet C (2020) Combining

559 geostatistics and simulations of flow and transport to characterize 560 contamination within the unsaturated zone. Sci Total Environ 699:134216. 
Pazzi V, Tapete D, Cappuccini L, Fanti R (2016) An electric and electromagnetic geophysical approach for subsurface investigation of anthropogenic mounds in

564 an urban environment. Geomorphology 273:335-347.

565 https://doi.org/10.1016/j.geomorph.2016.07.035

566 Priyanka BN, Kumar MSM, Arnai M (2018) Estimating anisotropic

567 heterogeneous hydraulic conductivity and dispersivity in a layered coastal

568 aquifer of Dakshina Kannada District, Karnataka. J Hydrol 565:302-317.

569 https://doi.org/10.1016/j.jhydrol.2018.08.031

570 Prudhomme KD, Khalil MA, Shaw GD, Speece MA, Zodrow KR, Malloy TM

571 (2019) Integrated geophysical methods to characterize urban subsidence in

572 Butte, Montana, U.S.A. J Appl Geophys 164:87-105.

573 https://doi.org/10.1016/j.jappgeo.2019.03.004

574 Raats PAC (1973) Dynamics of Fluids in Porous Media. Eng Geol 37(4):vi.

575 https://doi.org/10.2136/sssaj1973.03615995003700040004x

576 Rivett MO, Allen-King RM (2003) A controlled field experiment on groundwater

577 contamination by a multicomponent DNAPL: dissolved-plume retardation. J

578 Contam Hydrol 66:117-146. https://doi.org/10.1016/S0169-7722(03)00006-8

579 Rona M, Gasser G, Negev I, Pankratov I, Elhanany S, Lev O, Gvirtzman H (2014)

580 A 3-D hydrologic transport model of a water recharge system using

581 carbamazepine and chloride as tracers. Water Resour Res 50:4220-4241. 
582

583

591 the Nile Delta aquifer, Egypt. J Hydrol 464:186-198.

592 https://doi.org/10.1016/j.jhydrol.2012.07.007

593 Sidle RC, Nilsson B, Hansen M, Fredericia J (1998) Spatially varying hydraulic

594 and solute transport characteristics of a fractured till determined by field tracer

595 tests, Funen, Denmark. Water Resour Res 34:2515-2527.

596 https://doi.org/10.1029/98WR01735

597 Stisen S, Højberg A, Troldborg L, Refsgaard J, Christensen B, Olsen M,

598 Henriksen $\mathrm{H}$ (2012) On the importance of appropriate precipitation gauge

599 catch correction for hydrological modelling at mid to high latitudes. Hydrol

600 Earth Syst Sci 16:4157-4176. https://doi.org/10.5194/hess-16-4157-2012

601 Tao H, Liao X, Zhao D, Gong X, Cassidy DP (2019) Delineation of soil

602 contaminant plumes at a co-contaminated site using BP neural networks and 
geostatistics. Geoderma 354:113878.

604 https://doi.org/10.1016/j.geoderma.2019.07.036

605 Trowsdale SA, Lerner DN (2007) A modelling approach to determine the origin 606 of urban ground water. J Contam Hydrol 91:171-183.

607 https://doi.org/10.1016/j.jconhyd.2006.08.011

608 Vaezihir A, Bayanlou MB, Ahmadnezhad Z, Barzegari G (2020) Remediation of 609 BTEX plume in a continuous flow model using zeolite-PRB. J Contam Hydrol 610 230:103604. https://doi.org/10.1016/j.jconhyd.2020.103604

611 Vasin S, Carle A, Lang U, Kirchholtes HJ (2016) A groundwater management 612 plan for Stuttgart. Sci Total Environ 563:704-712.

613 https://doi.org/10.1016/j.scitotenv.2015.10.078

614 Vaudelet P, Schmutz M, Pessel M, Franceschi M, Guerin R, Atteia O, Blondel A,

615 Ngomseu C, Galaup S, Rejiba F, Begassat P (2011) Mapping of contaminant 616 plumes with geoelectrical methods. A case study in urban context. J Appl

617 Geophys 75:738-751. https://doi.org/10.1016/j.jappgeo.2011.09.023

618 Vazquez-Sune E, Sanchez-Vila X, Carrera J (2005) Introductory review of 619 specific factors influencing urban groundwater, an emerging branch of 620 hydrogeology, with reference to Barcelona, Spain. Hydrogeol J 13:522-533.

621 https://doi.org/10.1007/s10040-004-0360-2

622 Yang Y, Lerner DN, Barrett MH, Tellam JH (1999) Quantification of groundwater 623 recharge in the city of Nottingham, UK. Environ Geol 38:183-198. 
624 https://doi.org/10.1007/s002540050414

625 Yao LQ, Huo ZL, Feng SY, Mao XM, Kang SZ, Chen J, Xu JJ, Steenhuis TS (2014)

626 Evaluation of spatial interpolation methods for groundwater level in an arid

627 inland oasis, northwest China. Environ Earth Sci 71:1911-1924.

628 https://doi.org/10.1007/s12665-013-2595-5

629 Zuo R, Jin S, Chen M, Guan X, Wang J, Zhai Y, Teng Y, Guo X (2018) In-situ

630 study of migration and transformation of nitrogen in groundwater based on

631 continuous observations at a contaminated desert site. J Contam Hydrol

632 211:39-48. https://doi.org/10.1016/j.jconhyd.2018.03.003

633

634 

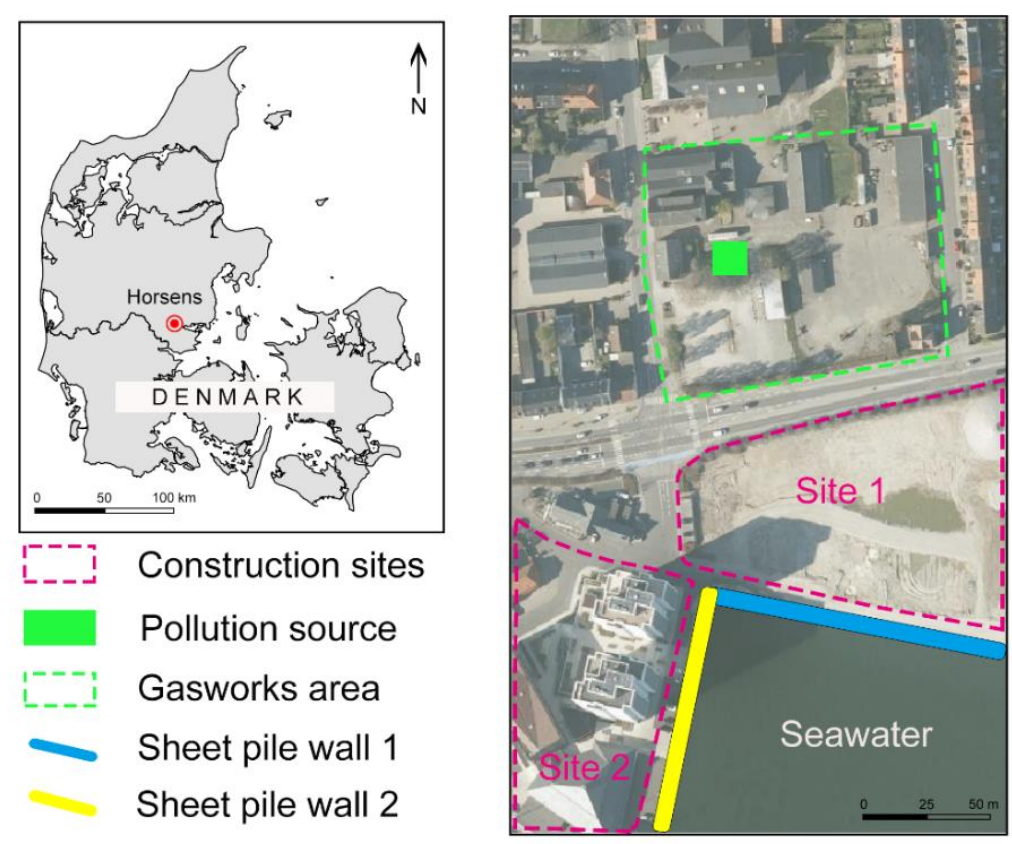

635

Fig. 1 Overview map of the study area

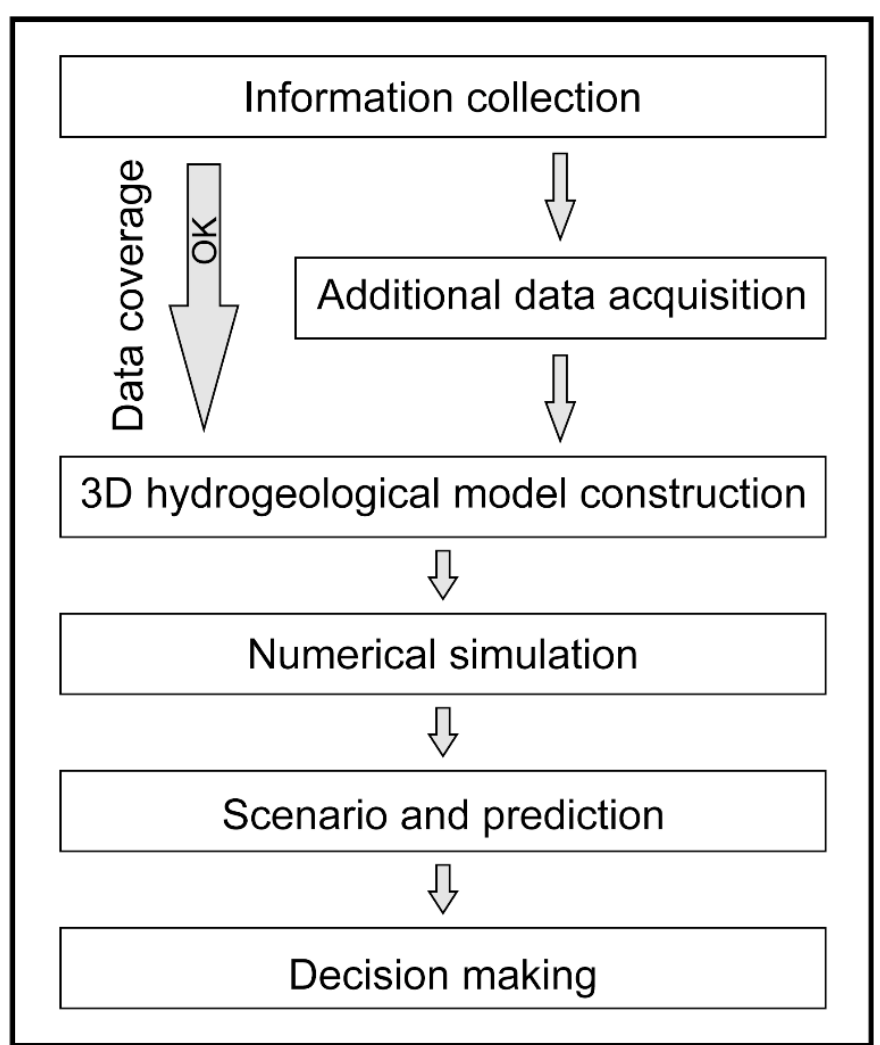




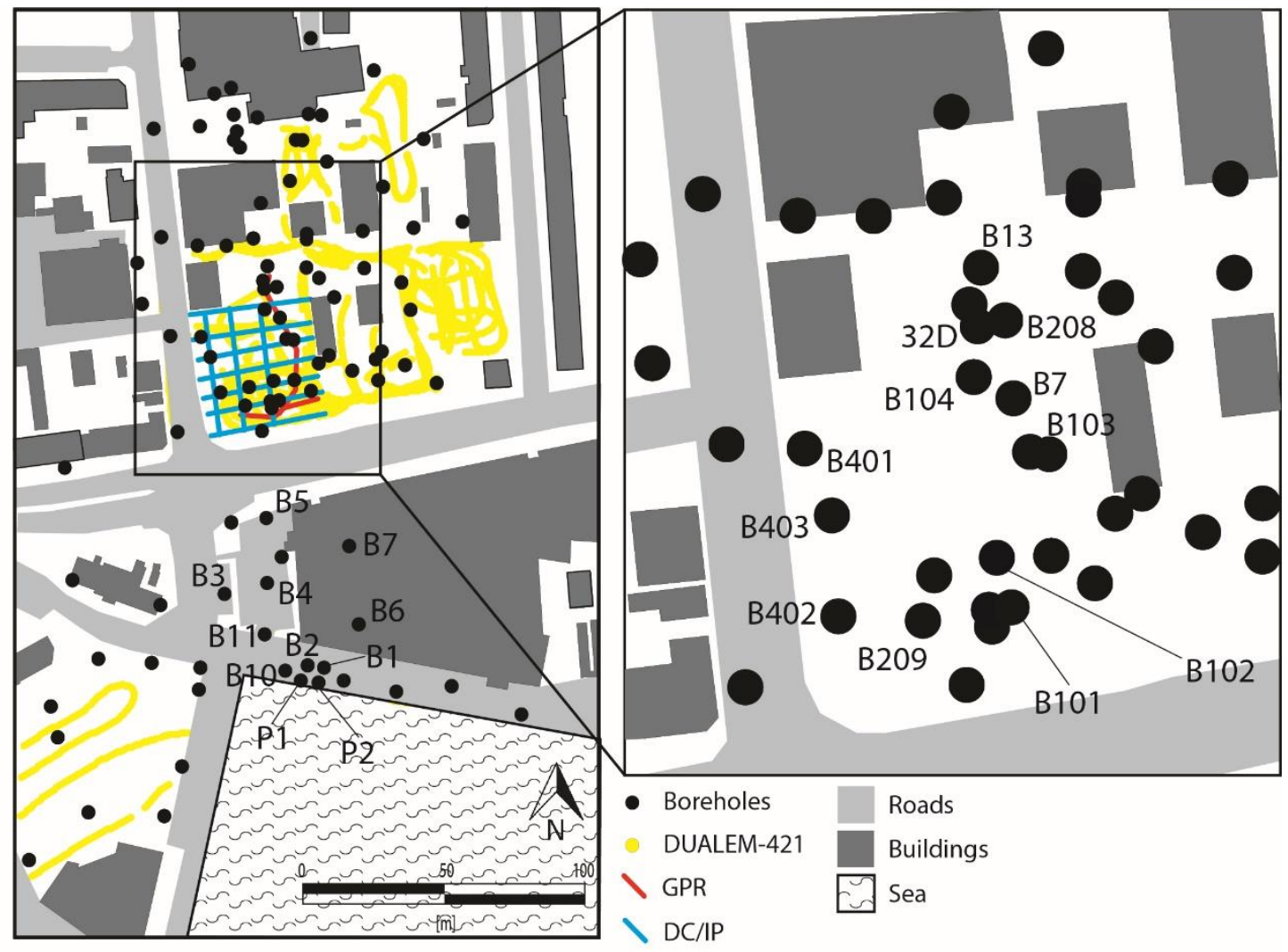

Fig. 3 Location of the boreholes and geophysical data

W
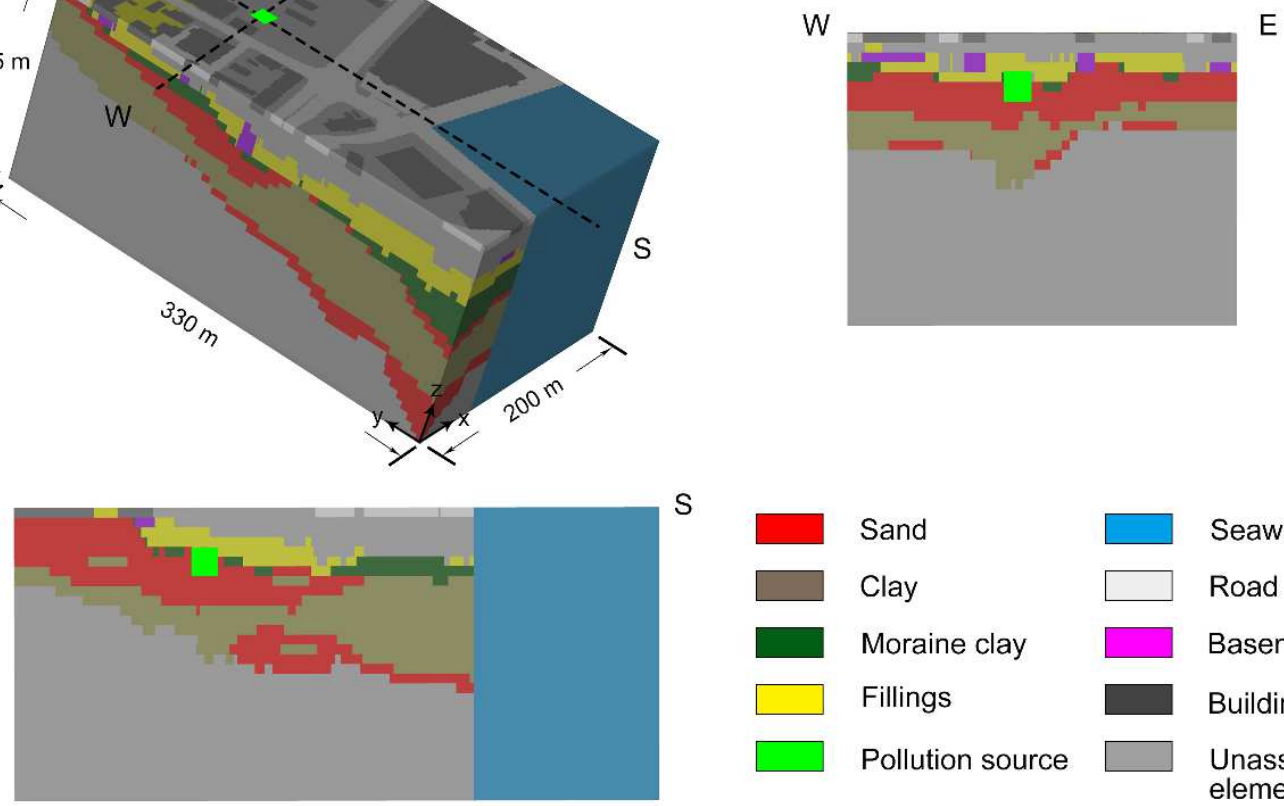

Sand

Clay

Moraine clay

Fillings

Pollution source

E

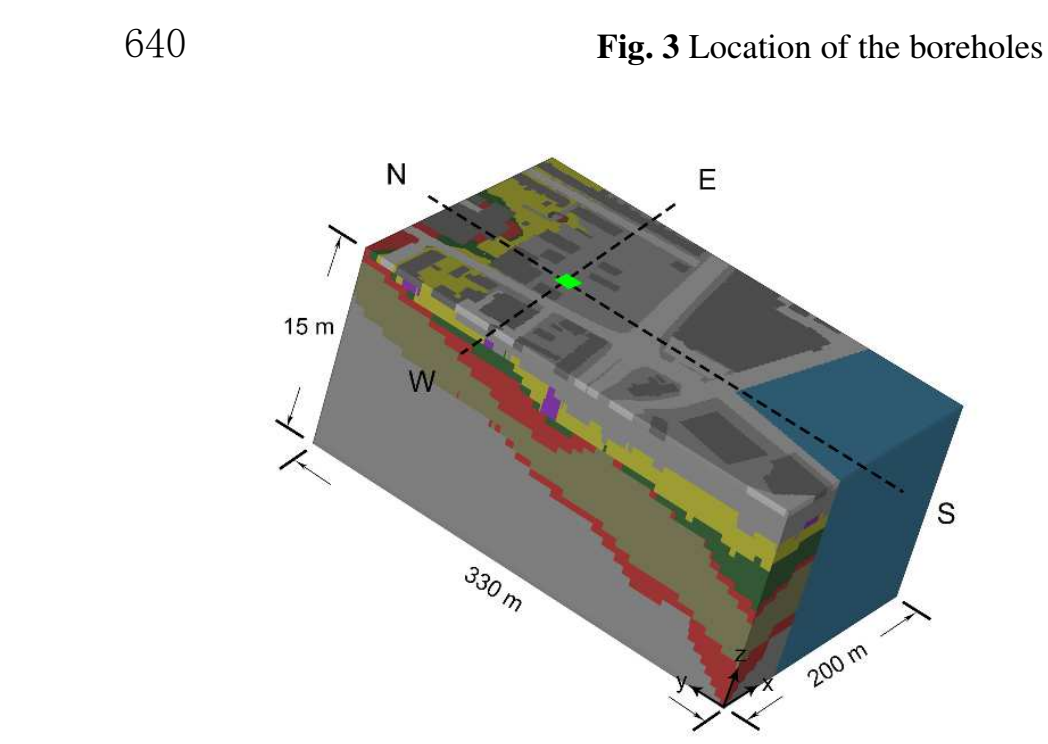

N

S
Seawater

Road

Basement

Building

Unassigned element

Fig.4 Appearance of the voxelised geological model in FEFLOW 


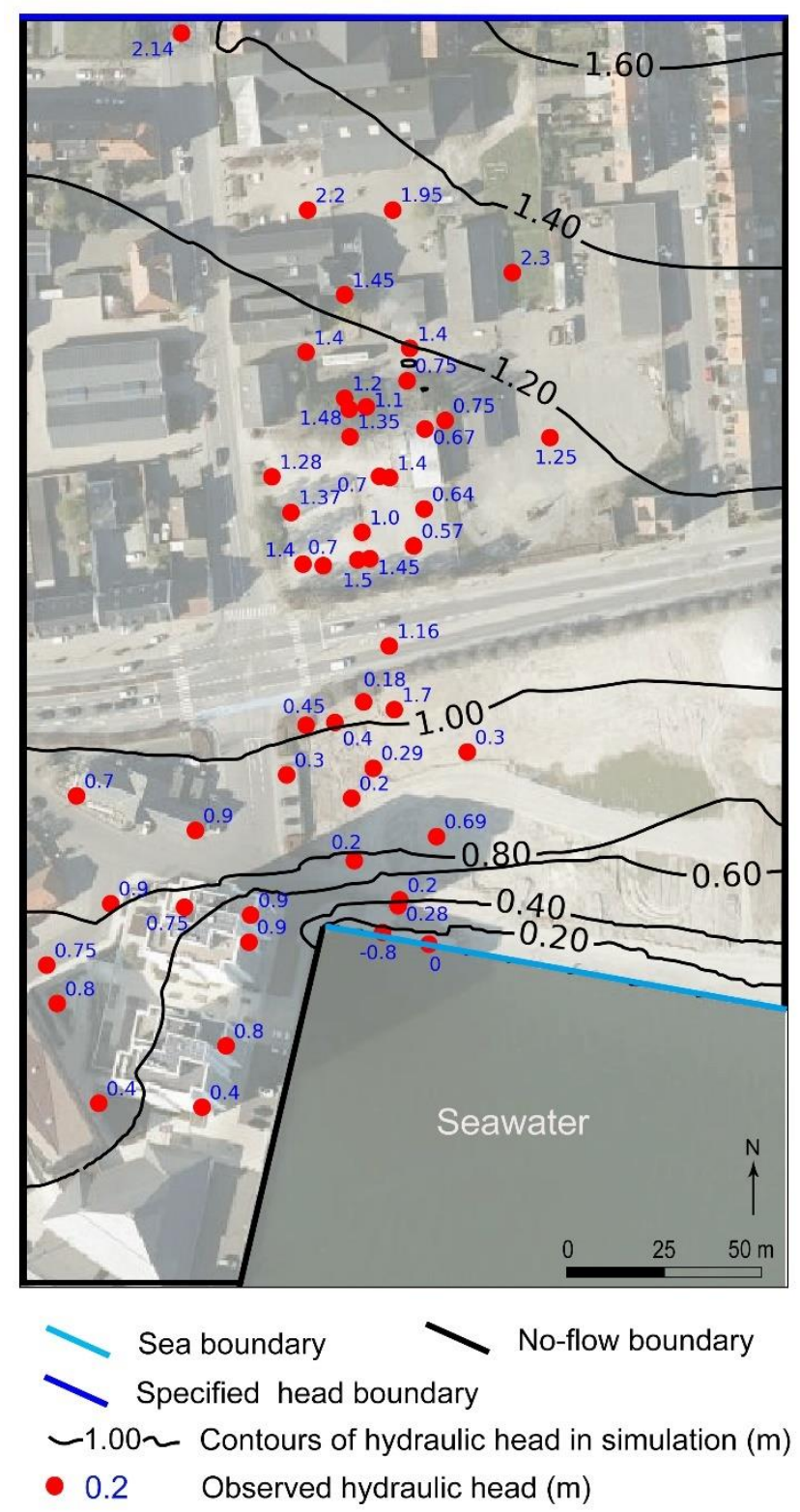

Fig.5 Observed hydraulic heads, boundary conditions and simulated hydraulic head of hydrogeological 645 model. $R M S E=0.4433 \mathrm{~m}$ 


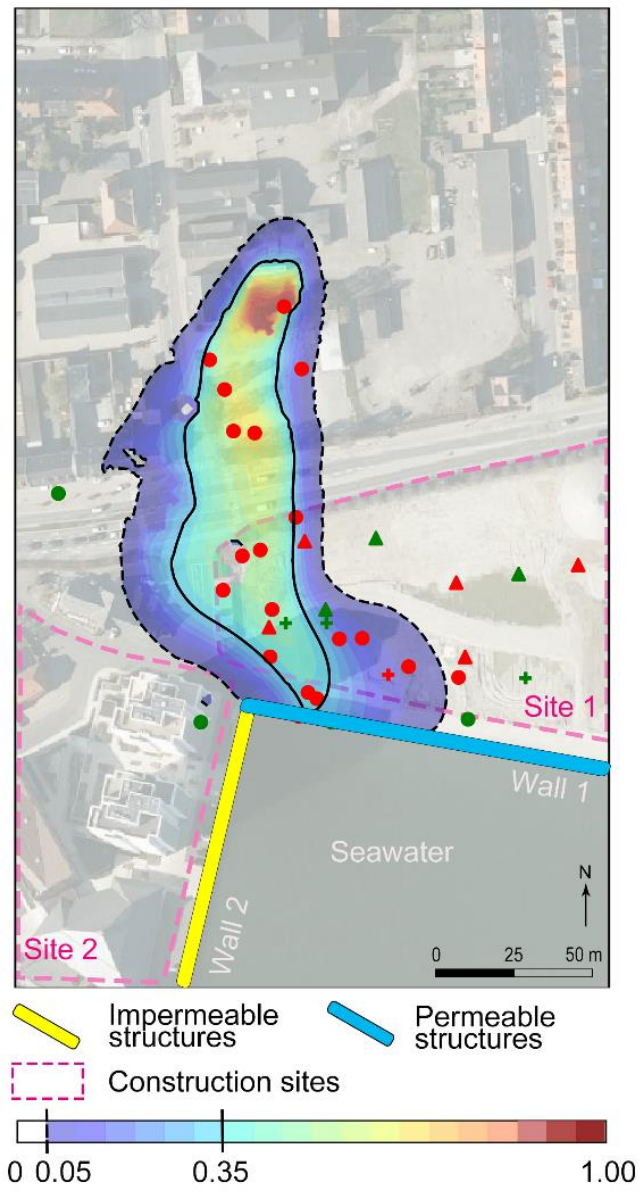

Fig.6 Modelled original contamination plume and results of analysed samples triangle indicates soil sample and cross indicates pore air sample.) 
a)
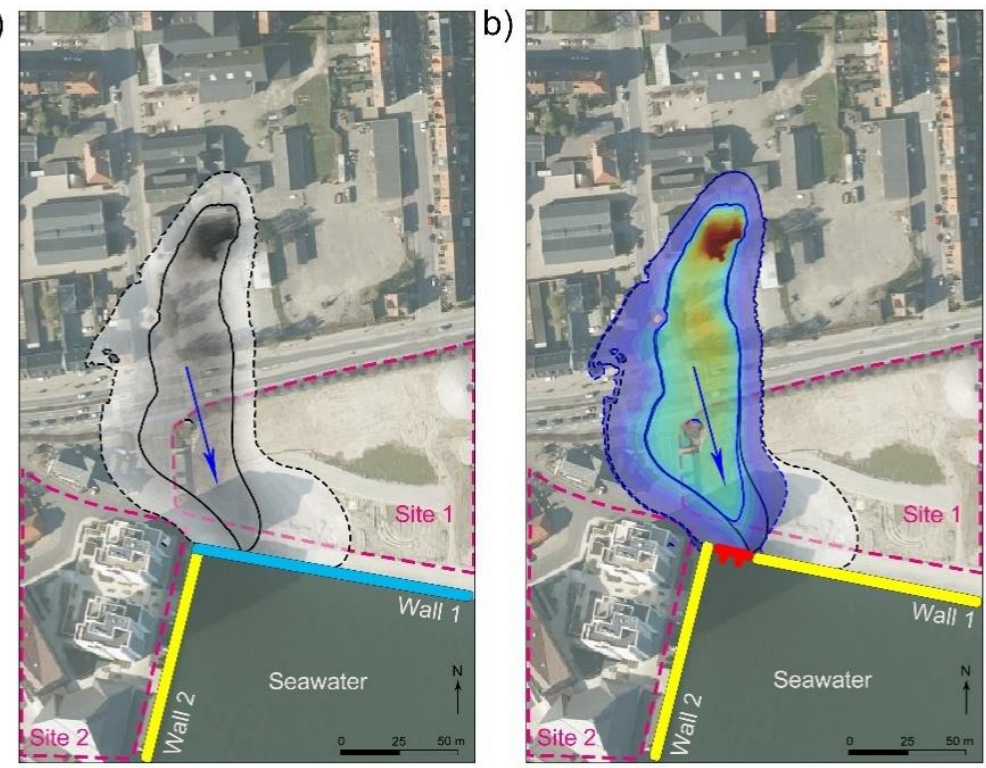

c)

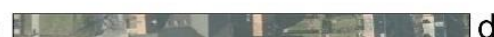

d)

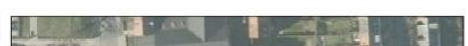

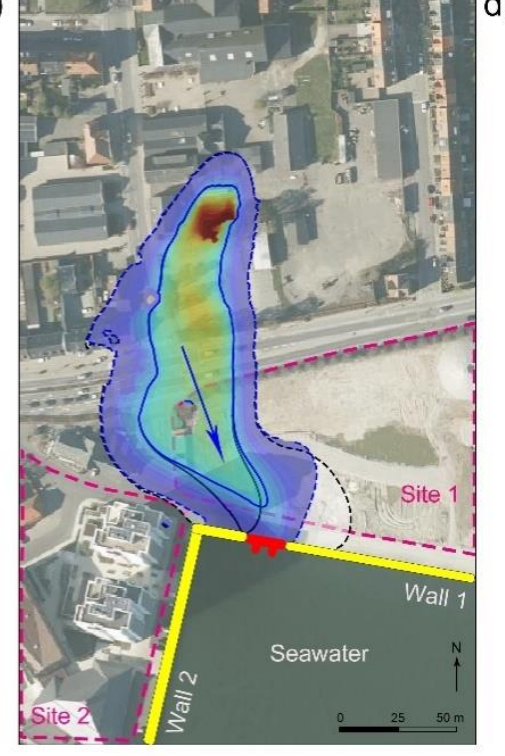

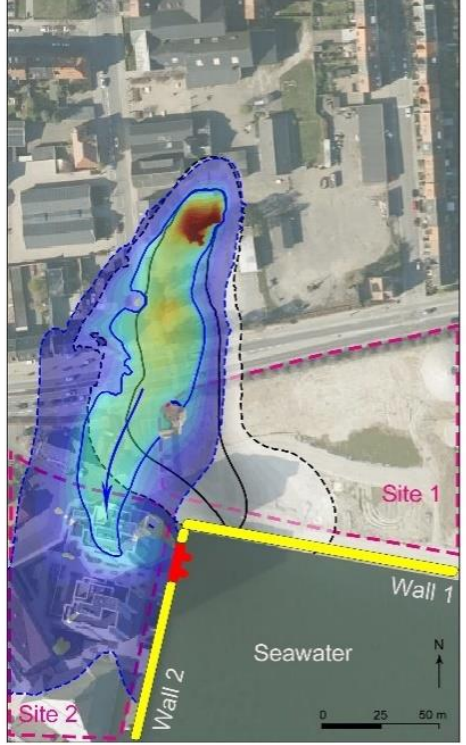

Construction sites $\bigcirc$ Impermeable structures

Permeable structures

Flow direction of contaminants

Or Outflow control facilities

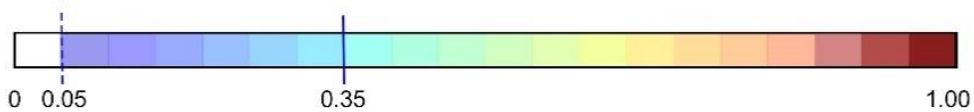

651 Fig.7 Results of original situation and scenarios. a) Original situation, Wall 1 was permeable and Wall 2

652 was impermeable. In b) scenario 1 and c) scenario 2, the outflow control facilities were both installed on

653 Wall 1 but a different location. d) scenario 3, the outflow control facilities were installed on Wall 2. The

654 colour-filled contour represents the contaminants plume distribution in different scenarios, while the

655 binary filled contour which showed in Fig.7 a. and partly covered in Fig.7 b-d shows the original

656 distribution of the contaminants plume. The values represented by the dashed and solid contour lines are

$657 \quad 0.05$ and 0.35 , respectively. 
Table.1 Input parameters for numerical simulation

\begin{tabular}{|c|c|c|c|c|}
\hline \multirow{9}{*}{ Fluid flow } & \multicolumn{2}{|l|}{ Inflow on the top $\left(\mathrm{mm} \cdot \mathrm{yr}^{-1}\right)$} & \multicolumn{2}{|c|}{212} \\
\hline & \multirow{3}{*}{${ }^{\mathrm{a}}$ Constant head boundary $(\mathrm{m})$} & Northern boundary & Upper sand 3.38 to 3.71 & Lower sand 1.75 to 2.02 \\
\hline & & Southwestern boundary & No-flow & No-flow \\
\hline & & Seawater & \multicolumn{2}{|c|}{0} \\
\hline & \multirow{5}{*}{ Material properties } & & Sand & 8.64 \\
\hline & & ${ }^{\mathrm{b}}$ Hydraulic conductivity $\left(\mathrm{m} \cdot \mathrm{d}^{-1}\right)$ & Clay & $8.64 \mathrm{E}-5$ \\
\hline & & (Horizontal : $\mathrm{K}_{\mathrm{xx}}=\mathrm{K}_{\mathrm{yy}}$ ) & Moraine clay & 1.3 \\
\hline & & & Fillings & 5.38 \\
\hline & & ${ }^{\mathrm{c}}$ Porosity & \multicolumn{2}{|c|}{0.3} \\
\hline \multirow{4}{*}{ Mass transport } & \multirow{2}{*}{${ }^{\mathrm{c}}$ Dispersivity (m) } & Transverse & \multicolumn{2}{|c|}{0.75} \\
\hline & & Longitudinal & \multicolumn{2}{|c|}{7.5} \\
\hline & \multirow{2}{*}{ Boundary conditions } & Contamination source & \multicolumn{2}{|c|}{1} \\
\hline & & Northern boundary & \multicolumn{2}{|c|}{0} \\
\hline
\end{tabular}

${ }^{a}$ The hydraulic head boundaries in the upper layers of sand were acquired from a regional model and interpolated by the linear method, while the boundaries in lower layers of sand were acquired from observation wells and interpolated by the Kriging method.

${ }^{\mathrm{b}}$ Vertical hydraulic conductivity $\left(\mathrm{K}_{\mathrm{zz}}\right)=10 \% \cdot$ Horizontal hydraulic conductivity $\left(\mathrm{K}_{\mathrm{xx}}, \mathrm{K}_{\mathrm{yy}}\right)$

${ }^{\mathrm{c}}$ Porosity and dispersivity values were set for all units 